\title{
Influence of Soil Environment and Surface Vegetation on Soil Micro Flora in a Coastal Sandy Belt of Orissa, India
}

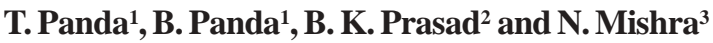 \\ 1. Department of Botany, S.N.College, Rajkanika 754 220, Orissa, India \\ E-mail: taranisenpanda@yahoo.co.in \\ 2. P.G. Department of Botany, Magadh University, Bodh-Gaya 824 234, Bihar, India \\ 3. Department of Zoology, Chandbali College, Chandbali 756 133, Orissa, India
}

KEYWORDS Coastal Sandy Belt. Micro-Flora. Distribution. Abundance

\begin{abstract}
A total of 141 species belonging 64 genera of fungi were isolated from coastal sandy belt of Orissa. The most dominant genera were Aspergillus, Penicillium, Trichoderma and Fusarium spp. Higher fungal and bacterial population was encountered in soil B than in soil A. Surface layer possessed higher fungal population, more soil nutrients and less moisture. Fungal population was positively correlated with total organic carbon, moisture content and total soil respiration but negatively correlated with soil temperature. Bacteria studied were maximum in June-July and minimum in January-February.
\end{abstract}

\section{INTRODUCTION}

The saprotrophs, one of the major functional components of a terrestrial ecosystem, are diverse in their occurrence. The role of the saprophytes in decomposition and its potentiality depends upon their count, composition and the higher plant/s with which the later coexist. Fungal population from diverse vegetation sites has earlier been studied (Miller et al.1957; Thornton 1960; Christensen et al. 1962; Gochenaur1978) and it has been concluded that soil microfungi show ecological and geo climatic specificity with response to environmental parameters (Orput and Curtis 1957; Christensen and Whittingham 1965; Christensen 1969). No work in this aspect has yet been done in coastal soil of Orissa, India. Therefore, the present work aims to find out the occurrence, distribution, dominance and variation of soil fungi and bacteria in the noted belt and the factors influencing their ecophysiology.

\section{STUDY SITE}

The site of study was Ganjam district of Orissa, $19^{\circ} .15^{\prime} \mathrm{N}$. Latitude and $84^{\circ} .50^{\prime}$ E. Longitude having $60 \mathrm{Km}$. of sea coast along the Bay of Bengal at a height of 6-8 above MSL. Cashew plantation at this site covers more than 150 hectares extending $4-5 \mathrm{Km}$. along the coast with a width of 250-450 $\mathrm{m}$. and a shelter belt plantation of Casuarina equisetifolia $\mathrm{L}$. having 10-15 rows covering 10$20 \mathrm{~m}$. along the coast.
The unproductive up-lands, coastal sand dunes and sandy beds are extensively covered by Casuarina equisetifolia $\mathrm{L}$. for soil conser-vation due to possessing tolerance against desiccation. The climate of the region is monsoonic with coastal characteristics. The atmospheric temperature ranges from $47^{\circ} \mathrm{C}$ in summer to $13^{\circ} \mathrm{C}$ in winter. The annual rainfall is about $130 \mathrm{~cm}$.

\section{MATERIAL AND METHODS}

Two experimental sites were selected from two different localities of the coastal belt situated quite apart from each other and were designated as Soil A and Soil B. Soil A represented a barren unproductive coastal sandy belt without vegetation. Soil B represented a coastal sandy bed with uni-culture plantation of Casuarina equisetifolia L. Sampling was done at monthly intervals. Distribution pattern of fungi and bacteria was assessed by adopting dilution (Waksman 1927) and direct plate technique (Warcup 1950) using potato dextrose agar medium. Physico-chemical properties of the soil were estimated adopting Jackson (1967). Soil metabolism was estimated by alkali absorption method (Witcamp 1966).

\section{RESULTS}

The temperature of the surface layer was higher than the sub surface layer (Table 1,2) just reverse to the moisture content. Soil B with low 
temperature and high moisture content has more fungal and bacterial population than soil A (Table 1,2). Other factors like total organic carbon, total nitrogen and $\mathrm{pH}$ were relatively higher in soil $\mathrm{B}$. In contrast, the soil A with higher temperature, low moisture and less soil nutrients was found to possess minimum fungal and bacterial propagules. Fungal population attained to its maximum in September and minimum in May in both the soils. Bacterial population attained its maximum in June-July and minimum in January-February in both the sites. Fungal population in both the sites and both the layers had positive correlation with soil moisture and total organic carbon, while the temperature was negatively correlated. The $\mathrm{pH}$ and total nitrogen proved insignificant.

Total of 3407 colonies, soil A contributed 1629 colonies of which surface soil had a share of 834 colonies, 54 genera and $91 \mathrm{spp}$. While sub surface soil produced 795 colonies, 46 genera and 80 species. Soil B contributed 1778 colonies; the surface soil contributed 903 colonies, 36 genera and 78 species while sub surface soil produced 875 colonies, 38 genera and 85 species. Deuteromycotina contributed maximum population followed by Ascomycotina and Zygomycotina
(Table 3, 4). The fungi that contributed more than $2.0 \%$ towards the total occurrence are enlisted with their ranks (Table 5, 6). This showed that Aspergillus spp. were the dominant followed by Penicillium, Trichoderma and Fusarium spp.

The evolution of $\mathrm{CO}_{2}$ was maximum during August-September and minimum in May in both the soil types. Similar trend of fungal population was observed which also had positive correlation with soil respiration

\section{DISCUSSION}

Thornton (1960), Christensen et al. (1962), Gochenaur and Whittingham (1967) and Kamal and Bhargava (1973) have reported that the prevailing climate and above ground vegetation are known to influence the abundance and quality of fungi in a particular soil. The presence of more fungi and bacteria in soil $\mathrm{B}$ with low temperature and high moisture than the soil $\mathrm{A}$ is similar to the findings of Rama Rao (1970), Kubat et al. (1979) and Behera and Mukherji (1985). The correlation between the fungal population and soil moisture and temperature accord to Eicker (1970). Marginal variations in $\mathrm{pH}$ at sites fail to

Table 1: Characteristics and total population of fungi and bacteria $\mathrm{g}^{-1} \mathrm{dry}$ soil in samples of soil B (average of two years)

\begin{tabular}{|c|c|c|c|c|c|c|c|c|}
\hline Months & $\begin{array}{l}\text { Tempera- } \\
\text { ture } \\
\left({ }^{\circ} \mathrm{C}\right)\end{array}$ & $\begin{array}{l}\text { Moisture } \\
\text { content } \\
(\%)\end{array}$ & $\begin{array}{c}\text { Total } \\
\text { organic carbon } \\
(\%)\end{array}$ & $\begin{array}{c}\text { Total } \\
\text { Nitrogen } \\
(\%)\end{array}$ & $p H$ & $\begin{array}{c}\text { Fungal } \\
\text { population } \\
\text { X } 10^{2}\end{array}$ & $\begin{array}{c}\text { Bacterial } \\
\text { population } \\
\times 10^{3}\end{array}$ & $\begin{array}{c}\mathrm{CO}_{2} \\
\text { Evolution } \\
M G / M T^{2} / H R\end{array}$ \\
\hline \multirow[t]{2}{*}{ DEC. } & $26.0 *$ & 0.38 & 0.38 & 0.0112 & 7.4 & 44.4 & 32.4 & 156 \\
\hline & $24.8 * *$ & 0.53 & 0.25 & 0.0098 & 7.5 & 40.8 & 42.1 & - \\
\hline \multirow[t]{2}{*}{ JAN } & $25.5 *$ & 0.35 & 0.38 & 0.0102 & 7.2 & 45.1 & 27.3 & 177 \\
\hline & $25.0 * *$ & 0.69 & 0.22 & 0.0095 & 7.6 & 46.4 & 30.6 & - \\
\hline \multirow[t]{2}{*}{ FEB. } & $27.0 *$ & 0.34 & 0.36 & 0.0137 & 7.1 & 48.7 & 36.9 & 211 \\
\hline & $26.0 * *$ & 0.62 & 0.22 & 0.011 & 7.4 & 43.5 & 33.4 & - \\
\hline \multirow[t]{2}{*}{ MAR. } & $31.8 *$ & 0.28 & 0.25 & 0.0156 & 6.9 & 43.8 & 33.7 & 150 \\
\hline & $30.1 * *$ & 0.56 & 0.18 & 0.0113 & 7.2 & 34.7 & 36.2 & - \\
\hline \multirow[t]{2}{*}{ APR. } & $35.5 *$ & 0.21 & 0.23 & 0.0152 & 7 & 33.2 & 40.5 & 124 \\
\hline & $32.8 * *$ & 0.51 & 0.15 & 0.0103 & 7.4 & 26.7 & 31.8 & - \\
\hline \multirow[t]{2}{*}{ MAY } & $38.8 *$ & 0.16 & 0.18 & 0.015 & 6.9 & 21.8 & 43.8 & 93 \\
\hline & $34.7 * *$ & 0.39 & 0.15 & 0.0103 & 7.2 & 17.1 & 37.9 & - \\
\hline \multirow[t]{2}{*}{ JUN. } & $33.0 *$ & 0.59 & 0.29 & 0.0156 & 7.1 & 34.4 & 46.9 & 136 \\
\hline & $332.5 * *$ & 0.36 & 0.26 & 0.0118 & 7.3 & 37.9 & 44.6 & - \\
\hline \multirow[t]{2}{*}{ JUL. } & $30.5 *$ & 0.9 & 0.34 & 0.0184 & 7 & 45.8 & 50.7 & 184 \\
\hline & $29.7 * *$ & 2.3 & 0.27 & 0.0123 & 7.2 & 47.1 & 41.3 & - \\
\hline \multirow[t]{2}{*}{ AUG. } & $30.0 *$ & 1.29 & 0.39 & 0.0159 & 7.1 & 47.5 & 45.4 & 189 \\
\hline & $29.0 * *$ & 3.09 & 0.3 & 0.0108 & 7.3 & 48.1 & 39.8 & - \\
\hline \multirow[t]{2}{*}{ SEPT. } & $29.5 *$ & 1.21 & 0.39 & 0.0137 & 6.9 & 53.2 & 52.3 & 215 \\
\hline & $28.4 * *$ & 3.02 & 0.33 & 0.011 & 7.2 & 51.9 & 43.9 & - \\
\hline \multirow[t]{2}{*}{ OCT. } & $28.5^{*}$ & 0.61 & 0.33 & 0.0143 & 7.1 & 42.4 & 47.3 & 248 \\
\hline & $27.5 * *$ & 1.52 & 0.3 & 0.0098 & 7.4 & 33.7 & 52.5 & - \\
\hline \multirow[t]{2}{*}{ NOV. } & $27.5^{*}$ & 0.48 & 0.35 & 0.0121 & 7.1 & 41.8 & 37.5 & 150 \\
\hline & $26.5 * *$ & 0.87 & 0.23 & 0.0098 & 7.8 & 29.9 & 44.3 & - \\
\hline
\end{tabular}

* Surface soil

$* *$ Sub surface soil 
Table 2: Characteristics and total population of fungi and bacteria $\mathrm{g}^{-1}$ dry soil in samples of soil A (average of two years)

\begin{tabular}{|c|c|c|c|c|c|c|c|c|}
\hline Months & $\begin{array}{l}\text { Tempera- } \\
\text { ture } \\
\left({ }^{\circ} \mathrm{C}\right) \\
\end{array}$ & $\begin{array}{c}\text { Moisture } \\
\text { content } \\
(\%)\end{array}$ & $\begin{array}{c}\text { Total } \\
\text { organic carbon } \\
(\%)\end{array}$ & $\begin{array}{l}\text { Total } \\
\text { Nitrogen } \\
(\%)\end{array}$ & $p H$ & $\begin{array}{c}\text { Fungal } \\
\text { population } \\
\text { X } 10^{2} \\
\end{array}$ & $\begin{array}{c}\text { Bacterial } \\
\text { population } \\
X 10^{3} \\
\end{array}$ & $\begin{array}{c}\mathrm{CO}_{2} \\
\text { Evolution } \\
M G / M T^{2} / H R\end{array}$ \\
\hline \multirow[t]{2}{*}{ DEC. } & $27.5^{*}$ & 0.24 & 0.24 & 0.011 & 7.8 & 36.1 & 26.7 & 135 \\
\hline & $27.0 * *$ & 0.36 & 0.19 & 0.016 & 7.7 & 44.2 & 24.9 & - \\
\hline \multirow[t]{2}{*}{ JAN } & $27.0 *$ & 0.28 & 0.28 & 0.011 & 8 & 40.8 & 21.9 & 141 \\
\hline & $26.8 * *$ & 0.41 & 0.23 & 0.01 & 7.9 & 46.2 & 22.1 & - \\
\hline \multirow[t]{2}{*}{ FEB. } & $29.3 *$ & 0.19 & 0.2 & 0.013 & 8 & 37.2 & 19.5 & 134 \\
\hline & $28.4 * *$ & 0.56 & 0.18 & 0.01 & 7.9 & 35.8 & 18.5 & - \\
\hline \multirow[t]{2}{*}{ MAR. } & $35.0 *$ & 0.17 & 0.19 & 0.009 & 8 & 35.1 & 25.1 & 87 \\
\hline & $31.0 * *$ & 0.51 & 0.17 & 0.009 & 7.7 & 28.1 & 24.8 & - \\
\hline \multirow[t]{2}{*}{ APR. } & $37.3 *$ & 0.17 & 0.14 & 0.01 & 7.5 & 25.4 & 29 & 80 \\
\hline & $35.5 * *$ & 0.46 & 0.13 & 0.01 & 7.5 & 23 & 39.8 & - \\
\hline \multirow[t]{2}{*}{ MAY } & $40.8^{*}$ & 0.12 & 0.13 & 0.011 & 7.4 & 22.1 & 32.4 & 71 \\
\hline & $38.8 * *$ & 0.31 & 0.12 & 0.013 & 7.3 & 18.1 & 43.4 & - \\
\hline \multirow[t]{2}{*}{ JUN. } & $36.5^{*}$ & 0.44 & 0.17 & 0.014 & 7.4 & 39.3 & 46.8 & 138 \\
\hline & $32.0 * *$ & 0.8 & 0.14 & 0.0093 & 7.3 & 31.5 & 45.8 & - \\
\hline \multirow[t]{2}{*}{ JUL. } & $32.5^{*}$ & 0.62 & 0.18 & 0.0093 & 7.2 & 43.7 & 35.2 & 126 \\
\hline & $30.8 * *$ & 1.71 & 0.16 & 0.012 & 7.3 & 41.3 & 37.2 & - \\
\hline \multirow[t]{2}{*}{ AUG. } & $31.0 *$ & 0.92 & 0.21 & 0.01 & 7.3 & 43.8 & 41.5 & 147 \\
\hline & $30.6 * *$ & 2.32 & 0.17 & 0.01 & 7.2 & 41.9 & 39.5 & - \\
\hline \multirow[t]{2}{*}{ SEPT. } & $31.0 *$ & 0.63 & 0.23 & 0.011 & 7 & 48.5 & 32.4 & 172 \\
\hline & $30.5 * *$ & 2.07 & 0.19 & 0.01 & 7.2 & 44.3 & 34.3 & - \\
\hline \multirow[t]{2}{*}{ OCT. } & $30.5 *$ & 0.48 & 0.22 & 0.01 & 7.2 & 33.3 & 48.8 & 181 \\
\hline & $29.5 * *$ & 1.35 & 0.15 & 0.009 & 7.4 & 36.2 & 28 & - \\
\hline \multirow[t]{2}{*}{ NOV. } & $28.5 *$ & 0.3 & 0.17 & 0.011 & 7.4 & 32.3 & 32.2 & 120 \\
\hline & $28.3 * *$ & 0.7 & 0.15 & 0.01 & 7.5 & 35.3 & 26.3 & - \\
\hline
\end{tabular}

* Surface soil

** Sub surface soil

Table 3: Special group distribution of fungus spp. in samples of soil B.(Observed by both methods)

\begin{tabular}{|c|c|c|c|c|c|c|c|c|}
\hline \multirow{3}{*}{$\begin{array}{l}\text { Name of the } \\
\text { groups }\end{array}$} & \multicolumn{8}{|c|}{ Surface (depth in cm.) } \\
\hline & \multicolumn{4}{|c|}{$0-3$} & \multicolumn{4}{|c|}{$8-15$} \\
\hline & $\begin{array}{c}\text { Numberof } \\
\text { genera }\end{array}$ & $\begin{array}{l}\% \text { of } \\
\text { total }\end{array}$ & $\begin{array}{c}\text { Number of } \\
\text { spp. }\end{array}$ & $\begin{array}{l}\% \text { of } \\
\text { total }\end{array}$ & $\begin{array}{c}\text { Numberof } \\
\text { genera }\end{array}$ & $\begin{array}{l}\% \text { of } \\
\text { total }\end{array}$ & $\begin{array}{c}\text { Number of } \\
\text { spp. }\end{array}$ & $\begin{array}{l}\% \text { of } \\
\text { total }\end{array}$ \\
\hline Zygomycotina & 5 & 13.9 & 7 & 9.0 & 3 & 7.9 & 5 & 5.9 \\
\hline Ascomycotina & 2 & 5.6 & 2 & 2.6 & 3 & 7.9 & 4 & 4.7 \\
\hline Deuteromycotina & 29 & 80.5 & 69 & 88.4 & 32 & 84.2 & 76 & 89.4 \\
\hline Moniliales & 24 & 82.8 & 64 & 92.8 & 21 & 65.6 & 65 & 85.6 \\
\hline Sphaeropsidales & 3 & 10.4 & 3 & 4.2 & 7 & 21.8 & 7 & 9.2 \\
\hline Melanconiales & 1 & 3.4 & 1 & 1.5 & 2 & 6.3 & 2 & 2.6 \\
\hline \multirow{2}{*}{ Mycelia sterilia } & 1 & 3.4 & 1 & 1.5 & 2 & 6.3 & 2 & 2.6 \\
\hline & 36 & 100 & 78 & 100 & 38 & 100 & 85 & 100 \\
\hline
\end{tabular}

Table 4: Special group distribution of fungus spp. in samples of soil A. (Observed by both methods)

\begin{tabular}{|c|c|c|c|c|c|c|c|c|}
\hline \multirow{3}{*}{$\begin{array}{l}\text { Name of the } \\
\text { groups }\end{array}$} & \multicolumn{8}{|c|}{ Surface (depth in cm.) } \\
\hline & \multicolumn{4}{|c|}{$0-3$} & \multicolumn{4}{|c|}{$8-15$} \\
\hline & $\begin{array}{c}\text { Numberof } \\
\text { genera }\end{array}$ & $\begin{array}{l}\% \text { of } \\
\text { total }\end{array}$ & $\begin{array}{c}\text { Number of } \\
\text { spp. }\end{array}$ & $\begin{array}{l}\% \text { of } \\
\text { total }\end{array}$ & $\begin{array}{c}\text { Numberof } \\
\text { genera }\end{array}$ & $\begin{array}{l}\% \text { of } \\
\text { total }\end{array}$ & $\begin{array}{c}\text { Number of } \\
\text { spp. }\end{array}$ & $\begin{array}{l}\% \text { of } \\
\text { total }\end{array}$ \\
\hline Zygomycotina & 6 & 11.1 & 6 & 7.7 & 3 & 6.5 & 4 & 5.0 \\
\hline Ascomycotina & 5 & 9.3 & 7 & 6.6 & 4 & 8.7 & 5 & 6.2 \\
\hline Deuteromycotina & 43 & 79.6 & 78 & 85.7 & 39 & 84.8 & 71 & 88.8 \\
\hline Moniliales & 30 & 55.6 & 65 & 71.4 & 27 & 58.6 & 59 & 73.8 \\
\hline Sphaeropsidales & 9 & 16.7 & 9 & 9.9 & 8 & 17.4 & 8 & 10 \\
\hline Melanconiales & 1 & 1.8 & 1 & 1.1 & 2 & 4.4 & 2 & 2.5 \\
\hline \multirow[t]{2}{*}{ Mycelia sterilia } & 3 & 5.5 & 3 & 3.3 & 2 & 4.4 & 2 & 2.5 \\
\hline & 54 & 100 & 91 & 100 & 46 & 100 & 80 & 100 \\
\hline
\end{tabular}


Table 5: Relative ranks of dominant fungi based on their \% abundance (above $2.0 \%$ ) recorded from the soil B.

\begin{tabular}{|c|c|c|c|c|c|c|c|}
\hline \multirow[t]{2}{*}{ S. No. } & \multirow[t]{2}{*}{ Fungi } & \multicolumn{3}{|c|}{ Surface soil } & \multicolumn{3}{|c|}{ Sub surface soil } \\
\hline & & $\begin{array}{c}\text { Number of } \\
\text { colonies }\end{array}$ & $\begin{array}{c}\% \\
\text { Contribution }\end{array}$ & Rank & $\begin{array}{l}\text { Number of } \\
\text { colonies }\end{array}$ & $\begin{array}{c}\% \\
\text { Contribution }\end{array}$ & Rank \\
\hline 1 & Trichoderma viride & 65 & 7.2 & 1 & 96 & 10.97 & 1 \\
\hline 2 & Penicillium verruculosum & 63 & 6.98 & 2 & 85 & 9.71 & 2 \\
\hline 3 & Aspergillus flavus & 62 & 6.86 & 3 & 19 & 2.17 & 14 \\
\hline 4 & Aspergillus niger & 55 & 6.09 & 4 & 72 & 8.22 & 3 \\
\hline 5 & Penicillum citrinum & 52 & 5.76 & 5 & 22 & 2.51 & 11 \\
\hline 6 & Fusarium spp. & 47 & 5.2 & 6 & 39 & 4.46 & 7 \\
\hline 7 & Aspergillus terreus & 34 & 3.77 & 7 & 69 & 7.89 & 4 \\
\hline 8 & Cladosporium cladosporioides & 32 & 3.54 & 8 & - & - & 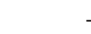 \\
\hline 9 & Aspergillus fumigatus & 30 & 3.32 & 9 & 45 & 5.14 & 6 \\
\hline 10 & Aspergillus awamori & 29 & 3.21 & 10 & 58 & 6.62 & 5 \\
\hline 11 & Cladosporium oxysporum & 26 & 2.88 & 11 & - & - & . \\
\hline 12 & Curvularia lunata & 23 & 2.55 & 12 & 28 & 3.2 & 8 \\
\hline 13 & Penicillium rubrum & 22 & 2.43 & 13 & 22 & 2.51 & 12 \\
\hline 14 & Drechslera australiensis & 21 & 2.32 & 14 & - & - & \\
\hline 15 & Absidia butleri & 20 & 2.21 & 15 & 21 & 2.4 & 13 \\
\hline 16 & Rhizopus nigricans & 20 & 2.21 & 16 & 26 & 2.97 & 9 \\
\hline 17 & Aspergillus candidus & 19 & 2.1 & 17 & - & - & 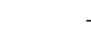 \\
\hline 18 & Penicillium minio-leuteum & - & - & - & 23 & 2.63 & 10 \\
\hline
\end{tabular}

Table 6: Relative ranks of dominant fungi based on their \% abundance (above $2.0 \%$ ) recorded from the soil A.

\begin{tabular}{|c|c|c|c|c|c|c|c|}
\hline \multirow[t]{2}{*}{ S. No. } & \multirow[t]{2}{*}{ Fungi } & \multicolumn{3}{|c|}{ Surface soil } & \multicolumn{3}{|c|}{ Sub surface soil } \\
\hline & & $\begin{array}{c}\text { Number of } \\
\text { colonies }\end{array}$ & $\begin{array}{c}\% \\
\text { Contribution }\end{array}$ & Rank & $\begin{array}{c}\text { Number of } \\
\text { colonies }\end{array}$ & $\begin{array}{c}\% \\
\text { Contribution }\end{array}$ & Rank \\
\hline 1 & Aspergillus nidulans & 124 & 14.97 & 1 & 40 & 5.03 & 2 \\
\hline 2 & Aspergillus awamori & 75 & 8.99 & 2 & 44 & 5.53 & 1 \\
\hline 3 & Aspergillus fumigatus & 58 & 6.95 & 3 & 33 & 4.15 & 4 \\
\hline 4 & Cladosporium cladosporioides & 56 & 6.71 & 4 & 34 & 4.28 & 3 \\
\hline 5 & Aspergillus niger & 45 & 5.38 & 5 & 28 & 3.52 & 8 \\
\hline 6 & Penicillum citrinum & 41 & 4.92 & 6 & 32 & 4.03 & 6 \\
\hline 7 & Curvularia lunata & 40 & 4.8 & 7 & 26 & 3.27 & 9 \\
\hline 8 & Curvularia eragrostidis & 36 & 4.32 & 8 & - & - & - \\
\hline 9 & Cytosporella spp. & 30 & 3.6 & 9 & - & - & - \\
\hline 10 & Paecilomyces varioti & 29 & 3.48 & 10 & 31 & 3.9 & 7 \\
\hline 11 & Chaetomium homopilatum & 28 & 3.36 & 11 & 32 & 4.03 & 5 \\
\hline 12 & Trichoderma viride & 25 & 3.0 & 12 & 25 & 3.14 & 10 \\
\hline 13 & Aspergillus terreus & 23 & 2.76 & 13 & 22 & 2.77 & 12 \\
\hline 14 & Cladosporium oxysporum & 19 & 2.28 & 14 & - & - & - \\
\hline 15 & Penicillium verruculosum & 18 & 2.16 & 15 & 23 & 2.89 & 11 \\
\hline 16 & Aspergillus flavus & 17 & 2.04 & 16 & - & - & - \\
\hline
\end{tabular}

influence the fungal population due to its trifle role (Menon and Williams 1957). Tresner et al. (1954) have reported that the composition of fungal species in communities is affected by aerial vegetation. Different vegetations supporting different communities of soil fungi have also been reported by Orput and Curtis (1957), Thornton (1960) and Christensen (1969). A comparison of the fungal population at two sites indicates that, the quantitative and qualitative differences of the surface vegetation were reflected by similar alterations in the micro fungal inhabitants. In fact, soil B harboured maximum and soil $\mathrm{A}$, the minimum fungal population.

The seasonal variations seem to influence the density of an individual fungus and population as a whole. The rainy carried higher population followed by winter and summer. Higher moisture content and temperature of sand corresponding to the rains and summer might be the reason for such fluctuation. The species composition at two sites shows marked difference with change in habitat and surface vegetation. Also, the fluctuation of ranks of the dominant species can 
be attributed to the change in the nutrient status of the soil. The order Dueteromycotina < Ascomycotina $<$ Zygomycotina of occurrence might be due to ability of the fungi for survival of adversity and adjustment with the environment. $\mathrm{CO}_{2}$ output has been reported to be influenced by the soil temperature and the moisture (Kucera and Kirkham 1971; Clark and Coleman 1972) and possessed the correlation with microbial population (Ray and Srivastava 1982) is observed presently.

\section{CONCLUSION}

Colonization and decomposition of litter in soil is carried out by micro-organisms. Fungi are good competitive saprophytes able to exploit substrates fully. From this investigation some fungi may be detected which will decompose the leaves at a faster rate. As a result the nutrient status of the sand dune will be changed and the energy plantation can be replaced by suitable economic plants which will increase the economic status of the state.

\section{REFERENCES}

Behera N, Mukherji KG 1985. Seasonal variation and distribution of micro fungi in forest soils of Delhi. Folia Geo Bot ET Phyto, 20: 291-312.

Christensen M 1969. The soil micro fungi of dry to mesic conifer hard wood forests in northern Wisconsin. Ecology, 50: 9-27.

Christensen M, Whittingham WF 1965. The soil micro fungi of open bogs and conifer wamps in Wisconsin. Mycologia, 57: 882-896

Christensen M, Whittingham WF, Novak RO 1962. The soil micro fungi of wet mesic forest in southern Wisconsin. Mycologia, 54: 374-388.

Clark FE, Coleman DC 1972. Secondary productivity of below ground in Pawnee grassland US/IBP grassland Biome. Tech. Rep. No. 169 Colorado State Univ. Fort Collins, 23 p.
Eicker A 1970. Vertical distribution of fungi in Zulu land soils. Trans Br Mycol Soc, 55: 45-57.

Goechenaur SE 1978. Fungi of a long Island oak-birch forest. 1. Community organization and seasonal occurrence of opportunistic decomposers of the A horizon. Mycologia, 70: 975-994.

Goechenaur SE, Whittingham WF 1967. Mycoecology of willow and cottonwood low land communities in southern Wisconsin. 1. Soil micro fungi in the willow cottonwood forests. Mycopath Mycol Appl, 33: 125139.

Jackson ML 1967. Soil Chemical Analysis. New Delhi: Prentice Hall Pvt. Ltd.

Kamal, Bhargava KS 1973. Studies on soil fungi from teak forest of Gorakhpur X Edaphic factors and distribution of soil microfungi in teak stands of different ages. Proc Nat Acad Sci India, 43B: 9-16.

Kubat J, Kralova M, Novac M 1979. Influence of fluctuating temperature on soil microflora. Zbl Bakt Parasiteko Infek. Hyg Stuttgart, 134: 229-236.

Kucera CL, Kirkham DL 1971. Soil respiration studies in tall grass Prairie. Ecology, 52: 912-915.

Menon CL, Williams LE 1957. Effect of crop, crop residues, temperature and moisture on soil fungi. Phytopathology, 47: 559-564.

Miller JH, Giddens JE, Foster AA 1957. A survey of fungi of forest and cultivated soils of Georgia. Mycologia, 49: 779-808.

Orput PA, Curtis JT 1957. Soil micro fungi in relation to the Prairie continuum in Wisconsin. Ecology, 38: 628-637.

Ray B, Srivastava AK 1982. Decomposition of leaf litter in relation to microbial population in a tropical dry mixed deciduous forest. Pedobiologia, 24: 151-159.

Rama Rao P 1970. Studies on soil fungi. III Seasonal variation and distribution of micro fungi in some soils of Andhra Pradesh (India). Mycopath. Mycol Appl, 40: 277-298.

Thornton RH 1960. Growth of fungi in some forests and in grassland soils. In D Parkinson, JS.Waid (Eds,): The Ecology of Soil Fungi. Liverpool: Liverpool Univ. Press, pp. 84-91.

Tresner HD, Backus MP, Curtis JT 1954. Soil micro fungi in relation to the hard wood forest continuum in southern Wisconsin. Mycologia, 46: 314-333.

Waksman SA 1927. Principles of Soil Microbiology. Williams and Willikins Co. Baltimore, P. 897.

Warcup J H 1950. The soil plate method for isolation of fungi from soil. Nature, 166: 117-118.

Witcamp M 1966. Rate of carbon dioxide evolution from the forest floor. Ecology, 47: 492-494. 